\title{
Evaluation and Optimization of Tensile Strength Responses of Coir Fibres Reinforced Polyester Matrix Composites (CFRP) Using Taguchi Robust Design
}

\author{
Ugochukwu Chuka Okonkwo', Christian Ebele Chukwunyelu², Bright Uchenna Oweziem², \\ Okunzuwa Austine Ekuase ${ }^{2}$ \\ ${ }^{1}$ Department of Mechanical Engineering, Nnamdi Azikiwe University, Awka, Nigeria \\ ${ }^{2}$ National Engineering Design Development Institute (NEDDI), Nnewi, Nigeria \\ Email: chrisbel2k@yahoo.com
}

Received 20 May 2015; accepted 1 June 2015; published 4 June 2015

Copyright (C) 2015 by authors and Scientific Research Publishing Inc.

This work is licensed under the Creative Commons Attribution International License (CC BY). http://creativecommons.org/licenses/by/4.0/

(c) (i) Open Access

\begin{abstract}
In this study, control factors which included aspect ratio of fibres, volume fraction of fibres and fibres orientation were the focus for determining the optimum tensile strengths of coir fibres reinforced polyester resin composites. After using Archimedes principle to determine the volume fraction of fibres, tensile test was conducted on the samples of treated and untreated coir fibres reinforced polyester resin composites, respectively. For the optimum properties to be obtained, a Universal Testing Machine-TUE-C-100 was used for the conducted tensile tests which established the levels of control factors settings for quality characteristics needed to optimize the mechanical properties being investigated. Applying Taguchi robust design technique for the greater-the-better, the highest signal-to-noise ratio ( $\mathrm{S} / \mathrm{N}$ ratio) for the quality characteristics being investigated was obtained employing Minitab 16 software. The optimum values of the control factors were established for treated coir fibres reinforced polyester resin composites and untreated coir fibres reinforced polyester resin composites. The treated coir fibres reinforced polyester matrix composite has the optimum tensile strength of $42.7 \mathrm{~N} / \mathrm{mm}^{2}$ while the untreated coir fibres reinforced matrix composite has the optimum tensile strength of $21.9 \mathrm{~N} / \mathrm{mm}^{2}$. The reinforcement combinations of control factors contribute greatly to the tensile properties, and the treated coir fibres reinforced polyester composites are stronger in tension than the untreated coir fibres reinforced polyester composites.
\end{abstract}

\section{Keywords}

Taguchi, Coir Fibres, Tensile Strength, Control Factors, Composites

How to cite this paper: Okonkwo, U.C., Chukwunyelu, C.E., Oweziem, B.U. and Ekuase, O.A. (2015) Evaluation and Optimization of Tensile Strength Responses of Coir Fibres Reinforced Polyester Matrix Composites (CFRP) Using Taguchi Robust Design. Journal of Minerals and Materials Characterization and Engineering, 3, 225-236.

http://dx.doi.org/10.4236/jmmce.2015.34025 


\section{Introduction}

Natural fibres from different plants and animals have provided the raw materials to meet our need for fibres. No matter which climatic zone humans settled, they were able to utilize the fibres of native species to make products such as clothes, craft, buildings and cordage. Natural fibres offer many technical and ecological benefits for their use in reinforcing composites. Natural fibres present many advantages compared with synthetic fibres which make them attractive as reinforcements in composite materials. They come from abundant and renewable resources, which ensure a continuous fibre supply and a significant material cost saving to the plastics industry.

Owing to deep interests of using natural fibres as alternative resources to synthetic fibres as reinforcement for polymeric materials in the manufacturing of cheap, renewable and environmentally friendly composites [1], many research have been carried out on natural fibres likes kenaf, bamboo, jute, hemp, coir, sugarpalm and oil palm [2]-[6]. The results of those researches have shown that the advantages of these natural fibres include low weight, low cost, low density, high toughness, acceptable specific strength, enhanced energy recovery, recyclability and biodegradability [4] [6] [7].

Tensile strength of coir fibres reinforced polyester composites is the maximum stress the material will bear when it is subjected to a stretching load. Composites have been generally known to be specifically arranged to fit into different specifications that have desirable properties in corrosive environment; composites provide higher strength at a lower weight and have lower life-cycle costs that help in their evolution [8]. It gives rise to a good combination in mechanical property, thermal and insulating protection. Coir fibres are obtained easily from coconut husks which are normally used as fuel when dried. So, coir fibres can be explored as a potential reinforcement. Considering the potential and credibility of the natural fibres as reinforcements for composites, the results have shown that the natural fibre composites own good stiffness, but fail to reach the same level of strength as the glass fibre composites [9]. For that reason, the economic and technical potential of any manufacturing process can easily be achieved through a process that is run with the optimum parameters. Similarly, it was found that compressive strength, bending strength, tensile strength, and impact strength of the ukam and sisal fibre reinforced composite material were greatly influenced by alkalization treatment [10].

Taguchi technique is one of the most important optimization processes, and powerful tool for the design of high quality systems with individual and combined parameters from a minimum number of simulation trials [11] [12] [13]. This technique which is a multi-step process follows a certain sequence for the experiments to yield required process or product performance [11]. Control factors are to be considered while designing a fiberreinforced composite. Such factors include the volume fraction of fibre which shows the amount of fibre, which contributes to the stiffness and strength of composites, and the aspect ratio (L/D) that is ratio of fibre length (L) and the diameter (D) which also helps in improving the strength of a composite. Similarly, the orientation of fibres plays an important role in the strength of the composites. As one of the characteristics of fibre reinforced composites, the properties of composites can be arranged in such a way that they can undergo different types of loading conditions; this study considers these conditions in order to achieve an optimum setting for materials subjected to some working conditions. In this study, coir fibres and polyester were used as fillers/reinforcement and matrix respectively in producing composites. The composites were used to evaluate the tensile strength for different reinforcement combinations to achieve the optimum strength.

\section{Material and Methods}

In this study, coir fibres are used as the reinforcement; aqueous sodium hydroxide $(\mathrm{NaOH})$, potassium permanganate $\left(\mathrm{KMnO}_{4}\right)$ solid and acetone liquid are used for fibre chemical treatment; and polyester resin as the matrix. Traditional and experimental design of Taguchi methods are used to optimize the tensile strength of coir fibre reinforced polyester composite (CFRP).

\subsection{Coir Fibre Extraction and Chemical Treatment}

Coir fibres used for this work were sourced from coconut husk through a process called retting which is a curing process during which the husks are kept in an environment that encourages the action of naturally occurring microbes. This action partially decomposes the husk's pulp, allowing it to be separated into coir fibres and a residue called coir pith. The coconut husks used for this study were soaked in few buckets of water with some biodegradable materials that will increase decomposing organisms thereby reducing the retting period to four (4) 
months. After the retting process, loosed fibres were separated and washed. The clean fibres were spread loosely on the ground to naturally dry in the sun. Figure 1 shows the well dried coir fibres.

In this study, alkaline treatment was conducted on coir fibres by immersing them in $5 \%$ aqueous $\mathrm{NaOH}$ solution for 72 hours at room temperature for proper depolymerisation of cellulose, removal of lignin and better strength of coir. Afterwards the treated fibres were carefully spread on mat and then finally air dried. Thereafter, the alkaline treated coir fibres were dipped in permanganate solution at measured out concentrations of $50 \%$ in acetone for $10 \mathrm{~min}$ for neutralization of the alkaline treated fibres, as shown in Figure 2. As a result, the hydrophilic tendency of the coir fibres was reduced, and thus, the water absorption of CFRP composite decreased.

\subsection{Sample Formation and Determination of Mechanical Properties}

Simple hand lay-up process was followed for forming these CFRP composites.Composite formation using permanganate treated coir fibres and untreated coir fibres were carried out in a square mould of volume $300 \mathrm{~mm} \times$ $300 \mathrm{~mm} \times 7 \mathrm{~mm}$ in a matching group of $5 \%, 10 \%$ and $15 \%$ volume fractions and $10,20,30 \mathrm{~mm} / \mathrm{mm}$ aspect ratio based on design matrix [14].

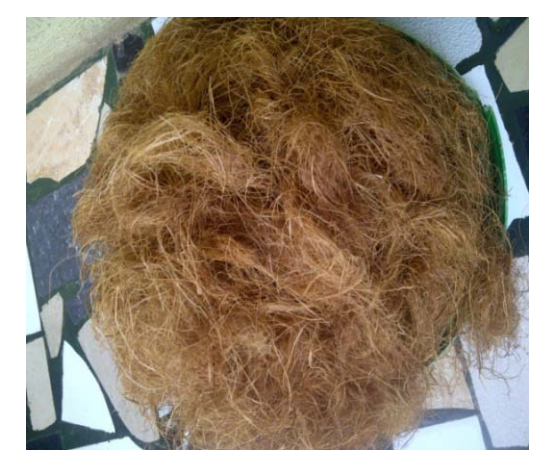

Figure 1. Dried coir fibres.

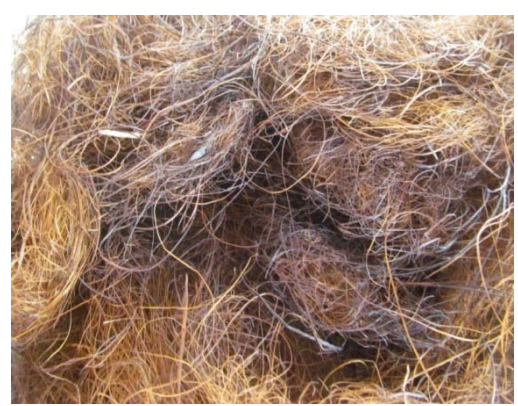

Figure 2. Permanganate treated coir fibres.

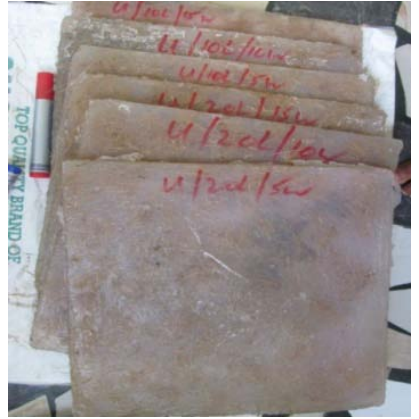

(a)

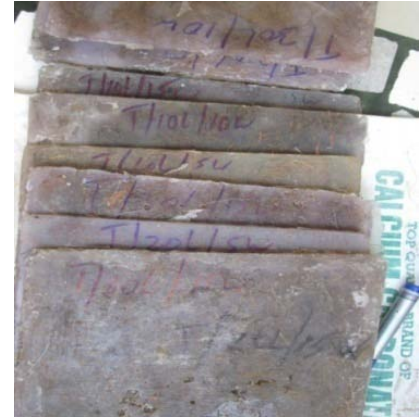

(b)

Figure 3. (a) Untreated coir-polyester composites; (b) Treated coirpolyester composites. 
Initially, the mould was polished; and poly vinyl acetate (PVA) mould release agent was applied on its surface before the fabrication. Afterwards, the binding mixture resin system consisting of unsaturated orthophthalic polyester, methyl ethyl ketone peroxide (MEKP) catalyst and cobalt naphthanate accelerator was prepared and used for the composites formation. The resin mixture was then poured on to the well dispersed coir fibre placed in the mould.

The CFRPs were pressed with a roller to avoid any air trap. When the coir fibres were completely wet by the resin, the mold was closed with a polished and PVA release agent surface-coated cover after the fabrication then pressed and cured at room temperature. At the time of curing, a compressive pressure of $0.05 \mathrm{MPa}$ was applied and maintained on the mold and the composite specimens were cured for 24 hours. Replicate samples of CFRP composites were formed. After curing, the required untreated and treated CFRP composites were obtained as shown in Figures 3(a)-(b), respectively.

\subsection{Design of Experiment (DOE)-Taguchi Experiment}

The Taguchi method involves reducing the variation in a process through robust design of experiments. The overall objective of the method is to produce high quality product at low cost to the manufacturer. The Taguchi method investigates how different parameters affect the mean and variance of a process performance characteristic that defines how well the process is functioning [14]. The experimental design proposed by Taguchi involves using orthogonal arrays to organize the parameters affecting the process and the levels at which they should be varied. This allows for the collection of the necessary data to determine which factors most affect product quality with a minimum amount of experimentation, thus saving time and resources [15].

The general steps involved in the Taguchi method are as follows:

1) Define the process objective, or more specifically, a target value for a performance measure of the process.

2) Determine the design parameters affecting the process. Parameters are variables within the process that affect the performance measure that can be easily controlled. The number of levels that the parameters should be varied and control factors must be specified as tabulated in Table 1. Increasing the number of levels to vary a parameter also increases the number of experiments to be conducted.

3) Create orthogonal arrays as shown in Table 2 for the parameter design indicating the number of and conditions for each experiment.

4) Conduct the experiments indicated in the completed array to collect data on the effect on the performance measure.

5) Complete data analysis to determine the effect of the different parameters on the performance measure.

The most important stage in the design of experiment lies in the selection of the control factors.

Table 1. Experimental outlay and variable sets for mechanical properties.

\begin{tabular}{ccccc}
\hline Control Factors & Level $\mathbf{1}$ & Level 2 & Level 3 & Units \\
\hline A: Aspect Ratio $\left(\mathbf{l}_{\mathbf{f}} / \mathbf{d}_{\mathbf{f}}\right)$ & 10 & 20 & 30 & $\mathrm{~mm} / \mathrm{mm}$ \\
B: Volume Fraction & 5 & 10 & 15 & $\%$ \\
C: Fibre Orientations & $0 / 90$ & $30 / 60$ & $45 / 45$ & degree \\
\hline
\end{tabular}

Table 2. Applicable taguchi standard orthogonal array L9 $\left(3^{3}\right)$.

\begin{tabular}{cccc}
\hline Experiment Number & Parameter 1: A & Parameter 2: B & Parameter 3: C \\
\hline $\mathbf{1}$ & 1 & 1 & 1 \\
$\mathbf{3}$ & 1 & 2 & 2 \\
$\mathbf{4}$ & 1 & 3 & 3 \\
$\mathbf{5}$ & 2 & 1 & 3 \\
$\mathbf{6}$ & 2 & 2 & 1 \\
$\mathbf{7}$ & 2 & 3 & 3 \\
$\mathbf{8}$ & 3 & 1 & 1 \\
$\mathbf{9}$ & 3 & 2 & 2 \\
\hline
\end{tabular}


The signal-to-noise ratio measures the sensitivity of the quality investigated to those uncontrollable factors (error) in the experiment. The higher value of $\mathrm{S} / \mathrm{N}$ ratio is always desirable, because greater $\mathrm{S} / \mathrm{N}$ ratio will result in smaller product variance around the target value. In order to perform $\mathrm{S} / \mathrm{N}$ ratio analysis, mean square deviation (MSD) for "the-larger-the-better" quality characteristic and S/N ratio were calculated from the following equations:

$$
\begin{gathered}
\mathrm{MSD}=\frac{1}{n} \sum_{i=1}^{N} \frac{1}{y_{i}^{2}} \\
\mathrm{~S} / \mathrm{N}=-10 \log _{10}(\mathrm{MSD})
\end{gathered}
$$

where, $y_{i}$ is a particular mechanical property for $i$ th replicate experiment.

\section{Results and Discussions}

\subsection{Evaluation and Discussion of Responses}

As a way of evaluating the tensile responses of the treated and untreated CFRP composites, an experimental design matrix using ASTM-D638 standard was done and the results were shown in Tables 3(a)-(b).

Similarly, an orthogonal array setting was used to evaluate the signal to noise ratios for the treated to noise ratios as shown in Tables 4(a)-(b) using Equation (2) already stated.

The tensile strengths of the treated and untreated CFRP composites were depicted using a stress-strain graph shown in Figures 4(a)-(b), respectively.

Table 3. Experimental design matrix for tensile test of treated CFRP composites (ASTM-D638).

(a)

\begin{tabular}{ccccccc}
\hline Expt. No. & $\begin{array}{c}\text { A: } \\
\text { Aspect Ratio } \\
{[\mathbf{l f} / \mathbf{d f}](\mathbf{m m})}\end{array}$ & $\begin{array}{c}\text { B: } \\
\text { Volume Fraction } \\
\mathbf{( \% )}\end{array}$ & $\begin{array}{c}\text { C: } \\
\text { Fibre Orientation } \\
\text { (Degree) }\end{array}$ & $\begin{array}{c}\text { Mean Tensile } \\
\text { Response-Treated } \\
\left(\mathbf{N} / \mathbf{m m}^{2}\right)\end{array}$ & MSD & S/N Ratio \\
\hline $\mathbf{1}$ & 10 & 5 & $0 / 90$ & 23.4483 & 0.00182 & 27.4022 \\
$\mathbf{2}$ & 10 & 10 & $30 / 60$ & 48.2758 & 0.00043 & 33.6746 \\
$\mathbf{3}$ & 10 & 15 & $45 / 45$ & 25.8621 & 0.00150 & 28.2533 \\
$\mathbf{4}$ & 20 & 5 & $30 / 60$ & 25.1724 & 0.00158 & 28.0185 \\
$\mathbf{5}$ & 20 & 10 & $45 / 45$ & 14.4483 & 0.00479 & 23.1963 \\
$\mathbf{6}$ & 20 & 15 & $0 / 90$ & 26.2069 & 0.00146 & 28.3683 \\
$\mathbf{7}$ & 30 & 5 & $45 / 45$ & 19.9655 & 0.00251 & 26.0056 \\
$\mathbf{8}$ & 30 & 10 & $0 / 90$ & 26.1032 & 0.00147 & 28.3339 \\
$\mathbf{9}$ & 30 & 15 & $30 / 60$ & 24.4828 & 0.00167 & 27.7772 \\
\hline
\end{tabular}

(b)

\begin{tabular}{ccccccc}
\hline Expt. No. & $\begin{array}{c}\text { A: } \\
\text { Aspect Ratio } \\
{[\mathbf{I f / d f ]}(\mathbf{m m})}\end{array}$ & $\begin{array}{c}\text { B: } \\
\text { Volume Fraction } \\
\mathbf{( \% )}\end{array}$ & $\begin{array}{c}\text { C: } \\
\text { Fibre Orientation } \\
\text { (Degree) }\end{array}$ & $\begin{array}{c}\text { Mean Tensile } \\
\text { Response-Untreated } \\
\left(\mathbf{N} / \mathbf{m m}^{2}\right)\end{array}$ & MSD & S/N Ratio \\
\hline $\mathbf{1}$ & 10 & 5 & $0 / 90$ & 13.1034 & 0.00582 & 22.3477 \\
$\mathbf{2}$ & 10 & 10 & $30 / 60$ & 11.7586 & 0.00723 & 21.4071 \\
$\mathbf{3}$ & 10 & 15 & $45 / 45$ & 12.0690 & 0.00687 & 21.6334 \\
$\mathbf{4}$ & 20 & 5 & $30 / 60$ & 16.3448 & 0.00374 & 24.2676 \\
$\mathbf{5}$ & 20 & 10 & $45 / 45$ & 12.5862 & 0.00631 & 21.9979 \\
$\mathbf{6}$ & 20 & 15 & $0 / 90$ & 15.5172 & 0.00415 & 23.8163 \\
$\mathbf{7}$ & 30 & 5 & $45 / 45$ & 14.8621 & 0.00453 & 23.4416 \\
$\mathbf{8}$ & 30 & 10 & $0 / 90$ & 24.1379 & 0.00172 & 27.6540 \\
$\mathbf{9}$ & 30 & 15 & $30 / 60$ & 16.5517 & 0.00365 & 24.3769 \\
\hline
\end{tabular}


Table 4. Evaluated quality characteristics, signal to noise ratios and orthogonal array setting for Tensile responses of treated CFRP.

(a)

\begin{tabular}{cccccc}
\hline Expt. No. & A & B & C & Mean Tensile Response-Treated (N/mm $\mathbf{2}^{\text {) }}$ & S/N Ratio \\
\hline $\mathbf{1}$ & 1 & 1 & 1 & 23.4483 & 27.4022 \\
$\mathbf{2}$ & 1 & 2 & 2 & 48.2758 & 33.6746 \\
$\mathbf{3}$ & 1 & 3 & 3 & 25.8621 & 28.2533 \\
$\mathbf{4}$ & 2 & 1 & 2 & 25.1724 & 28.0185 \\
$\mathbf{5}$ & 2 & 2 & 3 & 14.4483 & 23.1963 \\
$\mathbf{6}$ & 2 & 3 & 1 & 26.2069 & 28.3683 \\
$\mathbf{7}$ & 3 & 1 & 3 & 19.9655 & 26.0056 \\
$\mathbf{8}$ & 3 & 2 & 1 & 26.1032 & 28.3339 \\
$\mathbf{9}$ & 3 & 3 & 2 & 24.4828 & 27.7772 \\
\hline
\end{tabular}

(b)

\begin{tabular}{cccccc}
\hline Expt. No. & $\mathbf{A}$ & $\mathbf{B}$ & $\mathbf{C}$ & Mean Tensile Response-Untreated (N/mm $\mathbf{2}$ & S/N Ratio \\
\hline $\mathbf{1}$ & 1 & 1 & 1 & 13.1034 & 22.3477 \\
$\mathbf{2}$ & 1 & 2 & 2 & 11.7586 & 21.4071 \\
$\mathbf{3}$ & 1 & 3 & 3 & 12.0690 & 21.6334 \\
$\mathbf{4}$ & 2 & 1 & 2 & 16.3448 & 24.2676 \\
$\mathbf{5}$ & 2 & 2 & 3 & 12.5862 & 21.9979 \\
$\mathbf{6}$ & 2 & 3 & 1 & 15.5172 & 23.8163 \\
$\mathbf{7}$ & 3 & 1 & 3 & 14.8621 & 23.4416 \\
$\mathbf{8}$ & 3 & 2 & 1 & 24.1379 & 27.6540 \\
$\mathbf{9}$ & 3 & 3 & 2 & 16.5517 & 24.3769 \\
\hline
\end{tabular}

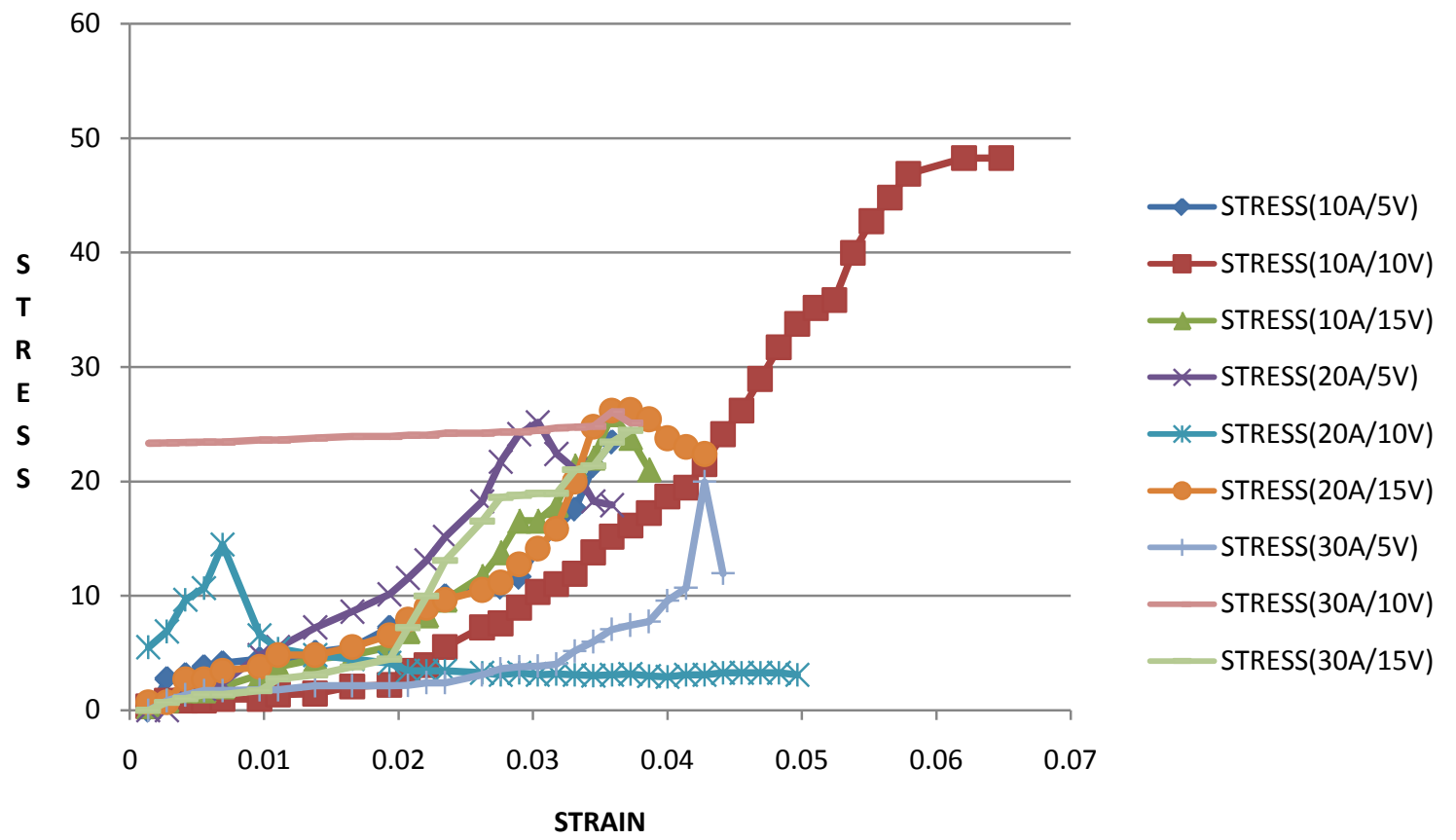

(a) 


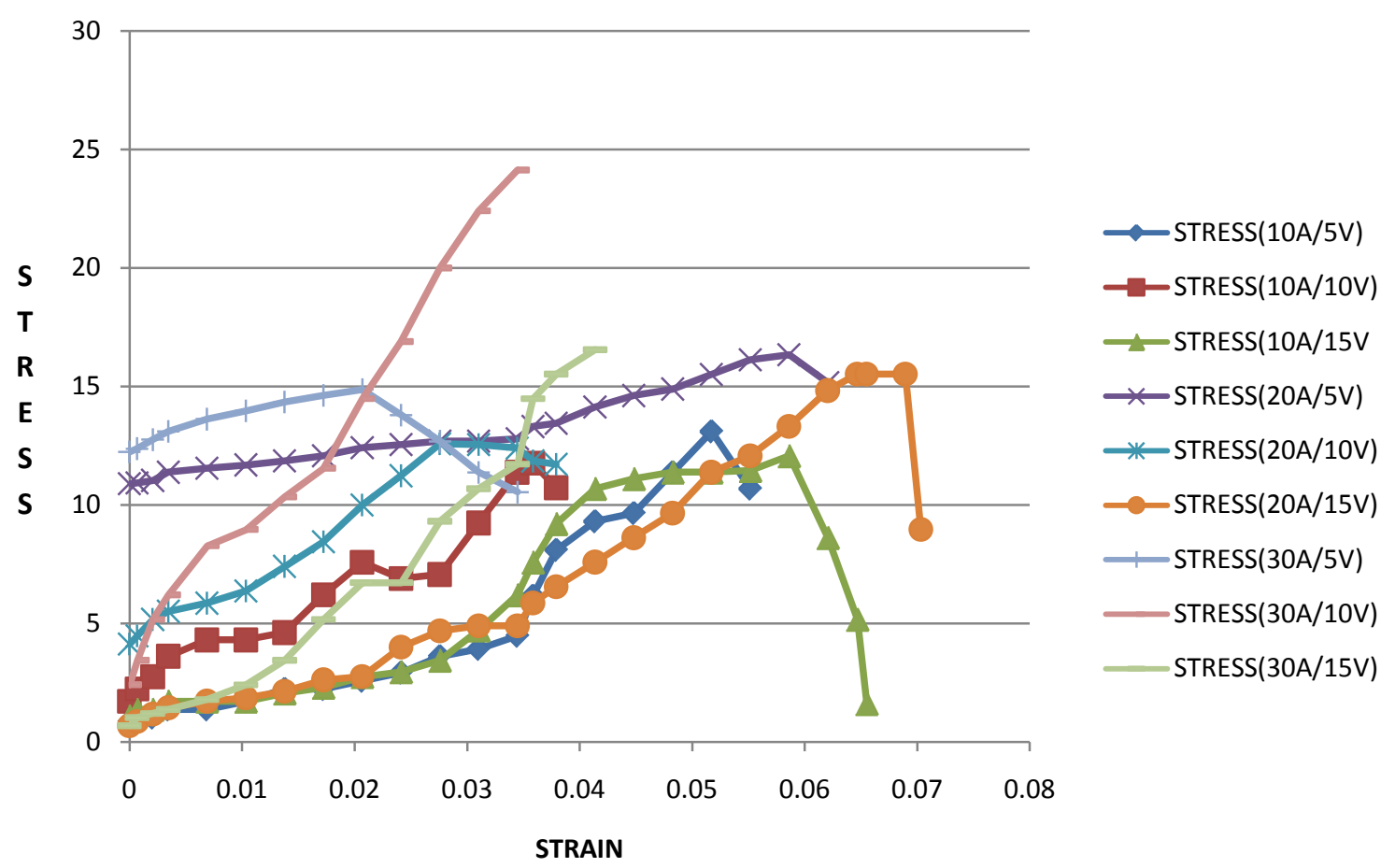

(b)

Figure 4. (a) Stress-Strain graph for Tensile strength of Treated CFRP; (b) Stress-Strain graph for Tensile strength of Untreated CFRP.

Table 5. (a) Average responses obtained for aspect ratio (A) at levels 1, 2, 3 within experiments 1 to 9 of treated CFRP for tensile response; (b) Average responses obtained for volume fraction (B) at levels 1, 2, 3 within experiments 1 - 9 of treated CFRP for tensile response; (c) Average responses obtained for fibre orientation (C) at levels 1, 2, 3 within experiments 1 - 9 of treated CFRP for tensile response.

(a)

\begin{tabular}{ccc}
\hline Quality Characteristics Factor Level & Average of Response for Different Experiment & Response Value \\
\hline SNav1 & $\left(\mathrm{A}_{1}+\mathrm{A}_{2}+\mathrm{A}_{3}\right) / 3$ & 29.7767 \\
Mms1 & $\left(\mathrm{A}_{1}+\mathrm{A}_{2}+\mathrm{A}_{3}\right) / 3$ & 32.5287 \\
SNav2 & $\left(\mathrm{A}_{4}+\mathrm{A}_{5}+\mathrm{A}_{6}\right) / 3$ & 26.5277 \\
Mms2 & $\left(\mathrm{A}_{4}+\mathrm{A}_{5}+\mathrm{A}_{6}\right) / 3$ & 21.9425 \\
SNav3 & $\left(\mathrm{A}_{7}+\mathrm{A}_{8}+\mathrm{A}_{9}\right) / 3$ & 27.3722 \\
Mms3 & $\left(\mathrm{A}_{7}+\mathrm{A}_{8}+\mathrm{A}_{9}\right) / 3$ & 23.5172 \\
\hline
\end{tabular}

(b)

$\begin{array}{ccc}\text { Quality Characteristics Factor Level } & \text { Average of Response for Different Experiment } & \text { Response Value } \\ \text { SNav1 } & \left(\mathrm{B}_{1}+\mathrm{B}_{2}+\mathrm{B}_{3}\right) / 3 & 27.1421 \\ \text { Mms1 } & \left(\mathrm{B}_{1}+\mathrm{B}_{2}+\mathrm{B}_{3}\right) / 3 & 22.8621 \\ \text { SNav2 } & \left(\mathrm{B}_{4}+\mathrm{B}_{5}+\mathrm{B}_{6}\right) / 3 & 28.4016 \\ \text { Mms2 } & \left(\mathrm{B}_{4}+\mathrm{B}_{5}+\mathrm{B}_{6}\right) / 3 & 29.6091 \\ \text { SNav3 } & \left(\mathrm{B}_{7}+\mathrm{B}_{8}+\mathrm{B}_{9}\right) / 3 & 28.1329 \\ \text { Mms3 } & \left(\mathrm{B}_{7}+\mathrm{B}_{8}+\mathrm{B}_{9}\right) / 3 & 25.5173\end{array}$


(c)

\begin{tabular}{ccc}
\hline Quality Characteristics Factor Level & Average of Response for Different Experiment & Response Value \\
\hline SNav1 & $\left(\mathrm{C}_{1}+\mathrm{C}_{2}+\mathrm{C}_{3}\right) / 3$ & 28.0365 \\
Mms1 & $\left(\mathrm{C}_{1}+\mathrm{C}_{2}+\mathrm{C}_{3}\right) / 3$ & 25.2528 \\
SNav2 & $\left(\mathrm{C}_{4}+\mathrm{C}_{5}+\mathrm{C}_{6}\right) / 3$ & 29.8234 \\
Mms2 & $\left(\mathrm{C}_{4}+\mathrm{C}_{5}+\mathrm{C}_{6}\right) / 3$ & 32.6437 \\
SNav3 & $\left(\mathrm{C}_{7}+\mathrm{C}_{8}+\mathrm{C}_{9}\right) / 3$ & 25.8184 \\
Mms3 & $\left(\mathrm{C}_{7}+\mathrm{C}_{8}+\mathrm{C}_{9}\right) / 3$ & 20.0920 \\
\hline
\end{tabular}

Table 6. (a) Average responses obtained for aspect ratio (A) at levels 1,2,3 within experiments 1 to 9 of untreated CFRP for tensile response; (b) Average responses obtained for volume fraction (B) at levels 1, 2, 3 within experiments 1 - 9 of untreated CFRP for tensile response; (c) Average responses obtained for fibre orientation (C) at levels 1, 2, 3 within experiments 1 - 9 of untreated CFRP for tensile response.

(a)

\begin{tabular}{ccc}
\hline Quality Characteristics Factor Level & Average of Response for Different Experiment & Response Value \\
\hline SNav1 & $\left(\mathrm{A}_{1}+\mathrm{A}_{2}+\mathrm{A}_{3}\right) / 3$ & 21.7961 \\
Mms1 & $\left(\mathrm{A}_{1}+\mathrm{A}_{2}+\mathrm{A}_{3}\right) / 3$ & 12.3103 \\
SNav2 & $\left(\mathrm{A}_{4}+\mathrm{A}_{5}+\mathrm{A}_{6}\right) / 3$ & 23.3606 \\
Mms2 & $\left(\mathrm{A}_{4}+\mathrm{A}_{5}+\mathrm{A}_{6}\right) / 3$ & 14.8161 \\
SNav3 & $\left(\mathrm{A}_{7}+\mathrm{A}_{8}+\mathrm{A}_{9}\right) / 3$ & 25.1575 \\
Mms3 & $\left(\mathrm{A}_{7}+\mathrm{A}_{8}+\mathrm{A}_{9}\right) / 3$ & 18.5172 \\
\hline
\end{tabular}

(b)

\begin{tabular}{ccc}
\hline Quality Characteristics Factor Level & Average of Response for Different Experiment & Response Value \\
\hline SNav1 & $\left(\mathrm{B}_{1}+\mathrm{B}_{2}+\mathrm{B}_{3}\right) / 3$ & 23.3523 \\
Mms1 & $\left(\mathrm{B}_{1}+\mathrm{B}_{2}+\mathrm{B}_{3}\right) / 3$ & 14.7701 \\
SNav2 & $\left(\mathrm{B}_{4}+\mathrm{B}_{5}+\mathrm{B}_{6}\right) / 3$ & 23.6863 \\
Mms2 & $\left(\mathrm{B}_{4}+\mathrm{B}_{5}+\mathrm{B}_{6}\right) / 3$ & 16.1609 \\
SNav3 & $\left(\mathrm{B}_{7}+\mathrm{B}_{8}+\mathrm{B}_{9}\right) / 3$ & 23.2755 \\
Mms3 & $\left(\mathrm{B}_{7}+\mathrm{B}_{8}+\mathrm{B}_{9}\right) / 3$ & 14.7126 \\
\hline
\end{tabular}

(c)

\begin{tabular}{ccc}
\hline Quality Characteristics Factor Level & Average of Response for Different Experiment & Response Value \\
\hline SNav1 & $\left(\mathrm{C}_{1}+\mathrm{C}_{2}+\mathrm{C}_{3}\right) / 3$ & 24.6060 \\
Mms1 & $\left(\mathrm{C}_{1}+\mathrm{C}_{2}+\mathrm{C}_{3}\right) / 3$ & 17.5862 \\
SNav2 & $\left(\mathrm{C}_{4}+\mathrm{C}_{5}+\mathrm{C}_{6}\right) / 3$ & 23.3505 \\
Mms2 & $\left(\mathrm{C}_{4}+\mathrm{C}_{5}+\mathrm{C}_{6}\right) / 3$ & 14.8850 \\
SNav3 & $\left(\mathrm{C}_{7}+\mathrm{C}_{8}+\mathrm{C}_{9}\right) / 3$ & 22.3576 \\
Mms3 & $\left(\mathrm{C}_{7}+\mathrm{C}_{8}+\mathrm{C}_{9}\right) / 3$ & 13.1724 \\
\hline
\end{tabular}

A standard approach to analyzing these data would be to use the analysis of variance (ANOVA) to determine which factors are statistically significant. But Taguchi approach uses a simpler graphical technique to determine which factors are significant. Since the $L_{9}$ experimental design is orthogonal it is possible to separate out the effect of each factor. This is done by looking at the control matrix for both the treated and untreated CFRP composites [16]; and calculating the average $\mathrm{S} / \mathrm{N}$ ratio (SNav) and mean (Mms) responses for each factor at each of the three test levels. These were shown in Tables 5(a)-(c) for treated CFRP and Tables 6(a)-(c) for the untreated CFRP.

The computations of Tables 3(a)-(b) were implemented in Minitab 16 software for the treated and untreated 
CFRP composites based on the larger is better quality characteristics and the results are shown in Tables 7(a)(b), respectively.

Figures 5(a)-(b) are the graphical illustrations of the mean effects plots for SN ratio of treated and untreated CFRP composites while Figures 6(a)-(b) are graphical depiction of the mean effects plots of the means based on larger is better characteristics.

The response tables for Means and SN ratios of Treated CFRP shows that the rankings are the same which implies that the higher value of ultimate tensile of treated CFRP at level 2 will give rise to a SN ratio effect that is of greater accurate which suggest the level of influence on treated CFRP. Therefore, the fibre orientation of treated CFRP has the highest contribution in influencing the composite tensile strength at level 2, followed with

Table 7. Response table for SN ratio and mean tensile strength of treated CFRP composites based on larger is better quality characteristics.

(a)

\begin{tabular}{ccccccc}
\hline Response & \multicolumn{3}{c}{ Signal-to-Noise Ratios } & \multicolumn{2}{c}{ Means } \\
\cline { 2 - 7 } Level & $\begin{array}{c}\text { A: } \\
\text { Aspect Ratio } \\
\left(\mathbf{l}_{\mathrm{f}} / \mathrm{d}_{\mathrm{f}}\right)\end{array}$ & $\begin{array}{c}\text { Volume Fraction } \\
(\%)\end{array}$ & $\begin{array}{c}\text { Fibre Orientations } \\
(\text { Degree })\end{array}$ & $\begin{array}{c}\text { A: } \\
\text { Aspect Ratio } \\
\left(\mathbf{l}_{\mathrm{f}} / \mathrm{d}_{\mathrm{f}}\right)\end{array}$ & $\begin{array}{c}\text { B: } \\
\text { Volume } \\
\text { Fraction (\%) }\end{array}$ & $\begin{array}{c}\text { Fibre Orientations } \\
\text { (Degree) }\end{array}$ \\
\hline $\mathbf{1}$ & 29.78 & 27.14 & 28.03 & 32.53 & 22.86 & 25.25 \\
$\mathbf{2}$ & 26.53 & 28.40 & 29.82 & 21.94 & 29.61 & 32.64 \\
$\mathbf{3}$ & 27.37 & 28.13 & 25.82 & 23.52 & 25.52 & 20.09 \\
Delta & 3.25 & 1.26 & 4.01 & 10.59 & 6.75 & 12.55 \\
Rank & 2 & 3 & 1 & 2 & 3 & 1 \\
\hline
\end{tabular}

(b)

\begin{tabular}{|c|c|c|c|c|c|c|}
\hline \multirow{2}{*}{$\begin{array}{c}\text { Response } \\
\text { Level }\end{array}$} & \multicolumn{3}{|c|}{ Signal-to-Noise Ratios } & \multicolumn{3}{|c|}{ Means } \\
\hline & $\begin{array}{c}\text { A: } \\
\text { Aspect Ratio } \\
\left(1_{\mathrm{f}} / \mathrm{d}_{\mathrm{f}}\right)\end{array}$ & $\begin{array}{c}\text { B: } \\
\text { Volume Fraction } \\
(\%)\end{array}$ & $\begin{array}{c}\text { C: } \\
\text { Fibre Orientations } \\
\text { (Degree) }\end{array}$ & $\begin{array}{c}\text { A: } \\
\text { Aspect Ratio } \\
\left(1_{\mathrm{f}} / \mathrm{d}_{\mathrm{f}}\right)\end{array}$ & $\begin{array}{c}\text { B: } \\
\text { Volume } \\
\text { Fraction }(\%)\end{array}$ & $\begin{array}{c}\text { C: } \\
\text { Fibre } \\
\text { Orientations (Degree) }\end{array}$ \\
\hline 1 & 21.80 & 23.35 & 24.61 & 12.31 & 14.77 & 17.59 \\
\hline 2 & 23.36 & 23.69 & 23.35 & 14.82 & 16.16 & 14.89 \\
\hline 3 & 25.16 & 23.28 & 22.36 & 18.52 & 14.71 & 13.17 \\
\hline Delta & 3.36 & 0.41 & 2.25 & 6.21 & 1.45 & 4.41 \\
\hline Rank & 1 & 3 & 2 & 1 & 3 & 2 \\
\hline
\end{tabular}

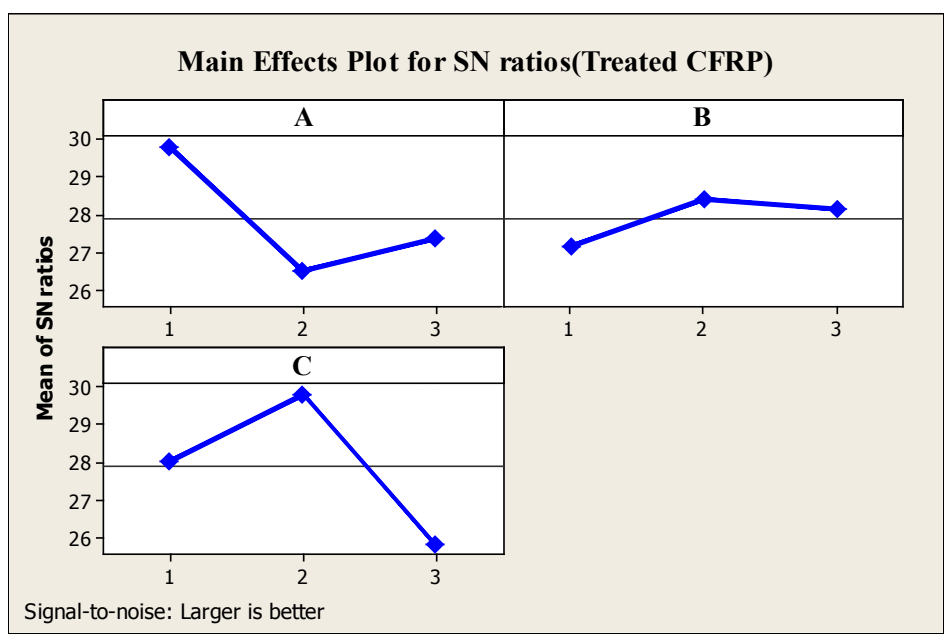

(a) 


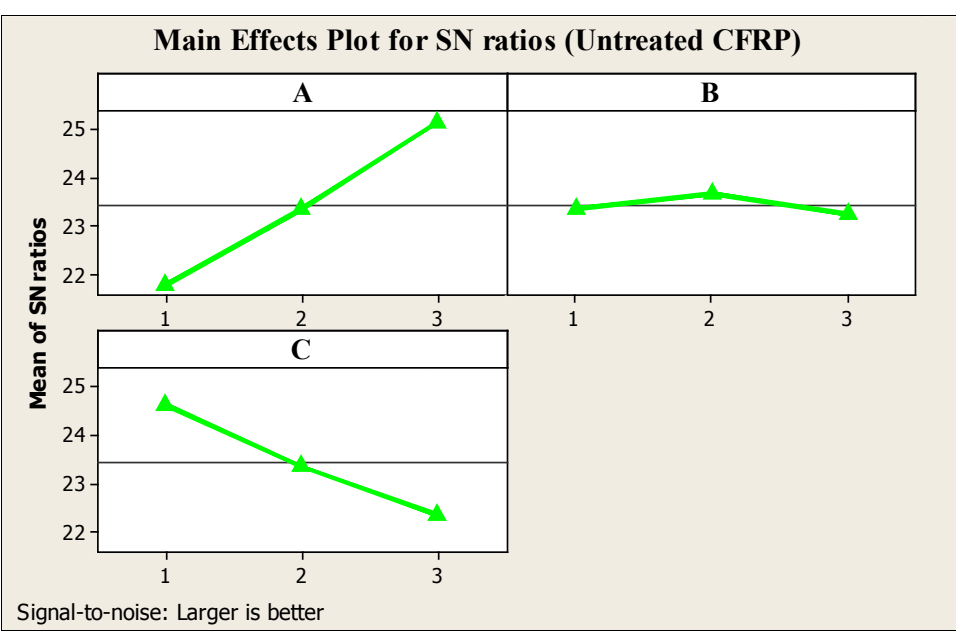

(b)

Figure 5. (a) Main effect plots for signal-noise ratios-treated CFRP; (b) Main effect plots for signal-to-noise ratio-untreated CFRP.

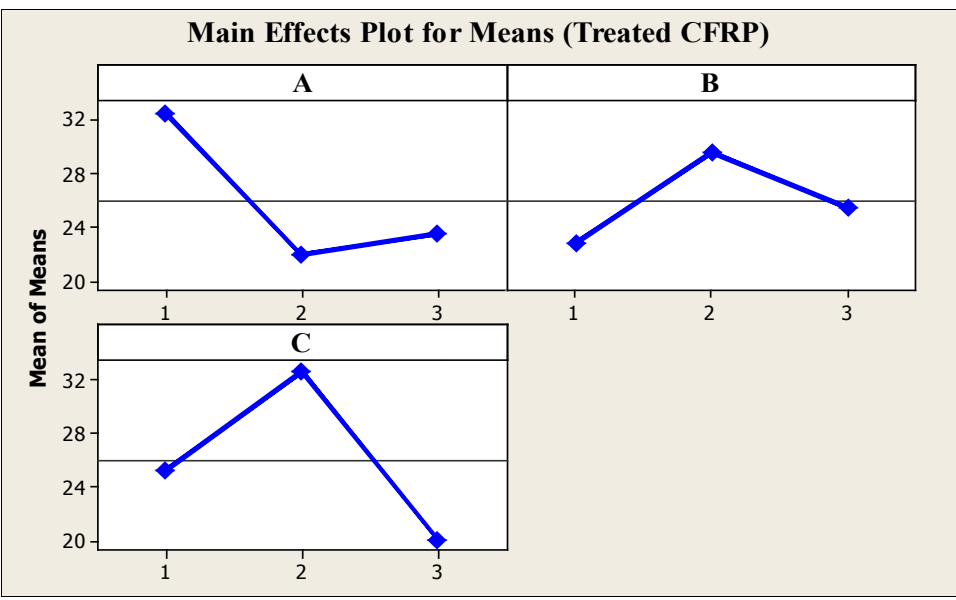

(a)

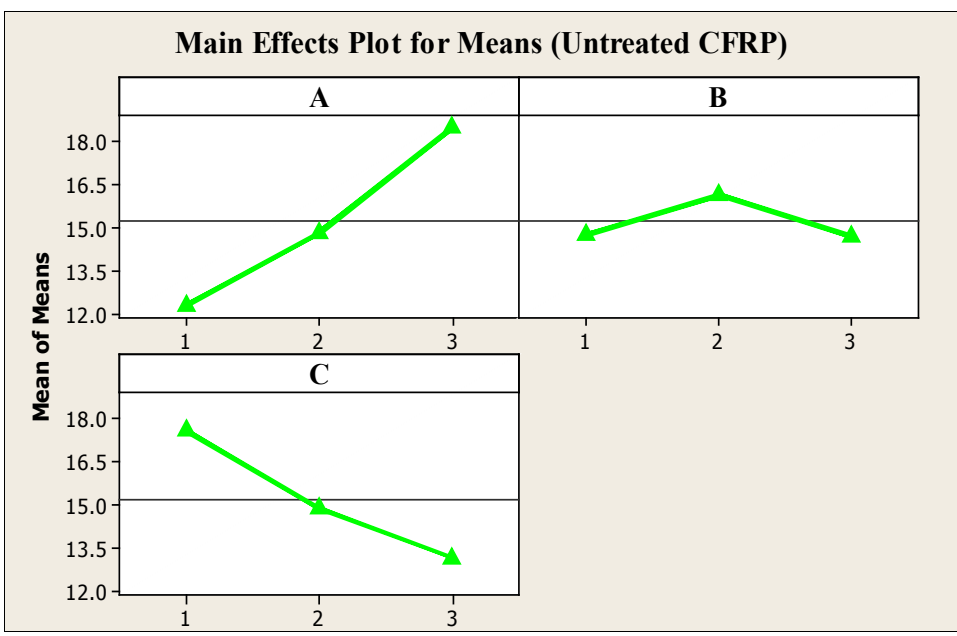

(b)

Figure 6. (a) Main effect plots for mean of means-treated CFRP; (b) Main effect plots for mean of means-untreated CFRP (tensile). 
Table 8. Optimum setting of control factors and expected optimum tensile strength of composites.

\begin{tabular}{ccccc}
\hline Composite/Property & Control Factor & Optimum Level & Optimum Setting & Expected Optimum Strength \\
\hline \multirow{2}{*}{ Treated CFRP/Tensile } & A & 1 & 10 & \\
& B & 2 & 10 & $42.7 \mathrm{~N} / \mathrm{mm}^{2}$ \\
Untreated CFRP/Tensile & C & 2 & $30 / 60$ & \\
& A & 3 & 30 & $21.9 \mathrm{~N} / \mathrm{mm}^{2}$ \\
\hline
\end{tabular}

aspect ratio at level 1. For untreated CFRP, the aspect ratio has the highest contribution in influencing the composite tensile strength at level 2 , followed with fibre orientation at level 1.

\subsection{Estimation of Expected Responses Based on Optimum Settings}

The expected response is estimated using the optimum control factor setting from the main effects plots; by employing the response table for signal to noise ratio and the response table for mean [17], the expected response model is stated thus:

$$
\mathrm{ER}=\mathrm{AVR}+\left(\mathrm{A}_{\mathrm{opt}}-\mathrm{AVR}\right)+\left(\mathrm{B}_{\mathrm{opt}}-\mathrm{AVR}\right)+\left(\mathrm{C}_{\mathrm{opt}}-\mathrm{AVR}\right)++\left(n_{\mathrm{opt}}^{\text {th }}-\mathrm{AVR}\right)
$$

where, $\mathrm{ER}=$ expected response, $\mathrm{AVR}=$ average response, $\mathrm{A}_{\mathrm{opt}}=$ mean value of response at optimum setting of factor $\mathrm{A}, \mathrm{B}_{\mathrm{opt}}=$ mean value of response at optimum setting of factor $\mathrm{B}, \mathrm{C}_{\mathrm{opt}}=$ mean value of response at optimum setting of factor $\mathrm{C}$.

As a result of plots of Figures 5(a)-6(b) at different Tensile Average Responses of Treated and Untreated CFRPs, one can conclude that the optimal settings of control parameters are as presented in Table 8 for both treated and untreated CFRP. Hence, the expected optimum strength for treated and untreated CFRP composite are of $42.7 \mathrm{~N} / \mathrm{mm}^{2}$ and $21.9 \mathrm{~N} / \mathrm{mm}^{2}$ respectively

The optimum settings of Tensile strength for treated and untreated CFRPs are the same in Volume fraction only but different in Aspect ratio and Fibre Orientation. It is also observed that the Expected Optimum Tensile strength of Treated CFRP is much greater than that of untreated CFRP because of difference in optimum setting in Fibre Orientation, the most influencing factor and Aspect Ratio.

\section{Conclusions}

Composites of different compositions were prepared, and the samples were characterized for their tensile properties. The following deductions can be drawn from the work:

1) The treated CFRP composite has the optimum tensile strength of $42.7 \mathrm{~N} / \mathrm{mm}^{2}$ when the control factors (aspect ratio of fibres, volume fraction of fibres and fibre orientation) are set $10,10 \%$ and 30/60 degree respectively, while untreated CFRP composite has the tensile strength of $21.9 \mathrm{~N} / \mathrm{mm}^{2}$ when the control factors (aspect ratio of fibres, volume fraction of fibres and fibre orientation) are set 30,10\% and 0/90 degree respectively;

2) The results indicate that fibre aspect ratio and fibre orientation are the most significant factors affecting the tensile strength of the composites. Although the effect of fibres volume fraction is significantly less for both treated and untreated coir, it cannot be ignored as it is one of the major load-bearing components in the composites.

The composites of treated coir are stronger in tension than those of untreated due to some reasons which include better hydrophobic nature and rough surface characteristics of the chemically treated coir which thereby enhance the composite formation.

\section{References}

[1] Srinivasa, C.V. and Bharath, K.N. (2011) Impact and Hardness Properties of Areca Fiber-Epoxy Reinforced Composites. Journal of Materials and Environment Science, 2, 351-356.

[2] Arib, R.M.N., Sapuan, S.M., Ahmad, M.M.H.M., Paridah, M.T. and Khairul Zaman, H.M.D. (2006) Mechanical Prop- 
erties of Pineapple Leaf Fiber Reinforced Polypropylene Composites. Materials \& Design, 27, 391-396. http://dx.doi.org/10.1016/j.matdes.2004.11.009

[3] Khairiah, B. and Khairul, A.M.A. (2006) Biocomposites from Oilpalm Resources. Journal of Oil Palm Research (Special Issue), 103-113.

[4] Lee, S.M., Cho, D., Park, W.H., Lee, S.G., Han, S.O. and Drzal, L.T. (2005) Novel Silk/Poly(butylene succinate) Biocomposites: The Effect of Short Fiber Content on Their Mechanical and Thermalproperties. Composites Science and Technology, 65, 647-657. http://dx.doi.org/10.1016/j.compscitech.2004.09.023

[5] Rozman, H.D., Saad, M.J. and MohdIshak, Z.A. (2003) Flexural and Impact Properties of Oil Palm Empty Fruit Bunch (EFB)-Polypropylene Composites-The Effect of Maleic Anhydride Chemical Modification of EFB. Journal of Polymer Testing, 22, 335-341. http://dx.doi.org/10.1016/S0142-9418(02)00109-5

[6] Sastra, H.Y., Siregar, J.P., Sapuan, S.M., Leman, Z. and Hamdan, M.M. (2005) Flexural Properties of Arenga pinnata Fiber Rein Forced Epoxy Composites. American Journal of Applied Sciences, (Special Issue), 21-24.

[7] Myrtha, K., Holia, O., Dawam, A.A.H. and Anung, S. (2008) Effect of Oil Palm Empty Fruit Bunch Fiber on the Physical and Mechanical Properties of Fiber Glass Reinforced Polyester Resin. Journal of Biological Sciences, 8, 101106. http://dx.doi.org/10.3923/jbs.2008.101.106

[8] Abdalla, F.H., Megat, M.H., Sapuan, M.S. and Sahari, B.B. (2008) Determination of Volume Fraction Values of Filament Wound Glass and Carbon Fiber Reinforced Composites. ARPN Journal of Engineering and Applied Sciences, $\mathbf{3}$, 7-11.

[9] Oksman, K.M. and Selin, J.F. (2003) Natural Fibres as Reinforcement in Polylacticacid (PLA) Composites. J. Comp. S. Skrivars ci. Technol., 63, 1317-1324.

[10] Samuel, O.D., Agbo, S. and Adekanye, T.A. (2012) Assessing Mechanical Properties of Natural Fibre Reinforced Composites for Engineering Applications. Journal of Minerals and Materials Characterization and Engineering, 11, 780-784. http://dx.doi.org/10.4236/jmmce.2012.118066

[11] Basavarajappa, S., Chandramohan, G. and Paulo, D.J. (2007) Application of Taguchi Techniques to Study Dry Sliding Wear Behaviour of Metal Matrix Composites. Materials and Design, 28, 1393-1398. http://dx.doi.org/10.1016/j.matdes.2006.01.006

[12] Taguchi, G. and Konishi, S. (1987) Taguchi Methods, Orthogonalarrays and Linear Graphs, Tools for Quality Engineering. American Supplier Institute, Dearborn, 35-38.

[13] Taguchi, G. (1993) Taguchi on Robust Technology Development Methods. ASME Press, New York, 1-40. http://dx.doi.org/10.1115/1.800288.ch1

[14] Design of Experiments. Minitab Inc. Copyright (C) 2003-2005.

[15] JMP Design of Experiments Release 6 (2005) Taguchi Design. SAS Institute Inc., Cary, ISBN 1-59047-816-9.

[16] Ihueze, C.C., Okafor, E.C. and Ujam, A.J. (2012) Optimization of Tensile Strengths Response of Plantain Fibres Reinforced Polyester Composites (PFRP) Applying Taguchi Robust Design. Innovative Systems Design and Engineering, 3, No. 7.

[17] Radharamanan, R. and Ansuj, A.P. (2001) Quality Improvement of a Production Process Using Taguchi Methods. Proceedings of Institute of Industrial Engineers Annual Conference, Dallas, Paper Solutions. 